\title{
Guns and Option Derivatives Are Rights: Two Must Be Analogously Priced
}

\author{
Monzurul Hoque \\ Saint Xavier University \\ Bruce Lipman \\ Chicago Police Department (Ret Lt) \\ David M. Parker \\ Saint Xavier University
}

Financial derivatives and guns can be significantly valuable tools. They can also be "weapons of mass destruction" that impose externalities on society. The last few years have demonstrated the need for stricter regulation, particularly regulation concerning risk-taking, in relation to both. In light of those externalities, laws and regulations used to identify, monitor, and mitigate risks are essential and legal intervention to regulate the risk of such externalities is justified. Regulation concerning risk-taking does carry high economic and social costs and should be carefully crafted. We posit that both guns and option derivatives are rights and must be appropriately priced to benefit society.

Keywords: financial weapons of destruction, option derivatives, financial externalities, risk-taking social costs, guns and financial options, Second Amendment, Wild Wild West

\section{INTRODUCTION}

The debate over the dangers that financial derivatives pose to the financial system is an old and ongoing one. For example, Warren Buffet has, on occasion, referred to financial derivatives as financial "time bombs" and "weapons of mass destruction" (Buffett, 2002; Buffett \& Munger, 2016). And yet, as Alan Greenspan once noted, although there are many critics of derivatives, the instruments are widely utilized because they provide significant economic value stating, "The performance of these increasingly complex financial instruments, especially over the past couple of stressful years, has been noteworthy. These financial products have contributed importantly to the development of a far more flexible and efficient financial system--both domestically and internationally--than we had just twenty or thirty years ago" (Greenspan, 2002). When either of these titans of finance speaks, it reminds one of an old E.F. Hutton \& Co. adage featured in its commercial showing everyone in a room going silent to hear the financial sage's advice. There is, however, an elephant in the room: How can these experts have such seemingly opposing opinions about the dangers posed by financial derivatives?

There is a similarly old and ongoing debate over the dangers posed by firearms ("firearms" or "guns"). The knowledge that gun use poses mortal dangers is nothing new. Many well-respected social scientists and criminal justice experts, however, have seemingly opposing opinions about these dangers. Some refer 
to firearms as "weapons of mass destruction" and advocate for strong regulation. Others assert that certain rights outweigh any dangers. It is fascinating and thought-provoking to observe gun-control proponents and gun-rights advocates squaring off in their duel.

Gun-control proponents frequently cite the high number of homicides and life-changing injuries involving guns to support their argument for more comprehensive gun control laws. Gun-rights advocates frequently note that firearms ownership can reduce crime, citing the value of guns as a means for selfprotection and for deterring violent crime. Gun-rights advocates often argue that limiting access to firearms by law-abiding individuals could make them more vulnerable to armed criminals because more comprehensive gun control laws will not deter criminals who are unlikely to obey firearms laws. Gun-rights advocates point to studies that support the value of gun ownership while minimizing the risk that guns pose. For example, in Targeting Guns: Firearms and Their Control, Kleck (1997) comprehensively reviewed research evidence on the links between guns, violence, and gun control and found no significant correlation between firearm ownership in general and gun violence. Other studies indicate that the ownership of a gun by an individual does not effectively determine how that individual's risk of victimization is affected by the gun ownership of others (Kellermann, et al., 1993). Marvin Wolfgang (1996), who is acknowledged as one of the world's most influential criminologists (Cohn \& Farrington, 1994), declared, "I am as strong a guncontrol advocate as can be found among the criminologists in this country." He continued, "If I were Mustapha Mond of The Rave New Work, I would eliminate all guns from the civilian population and maybe from the police." Moreover, "I hate guns - ugly, nasty instrument designed to kill people." And it is worth noting that he also states, "the Kleck and Gertz study impresses me for the caution the authors exercise and the elaborate nuances they examine methodologically. I do not like their conclusions that having a gun can be useful, but I cannot fault their methodology" (Wofgang, 1996).

\section{WHY CARRY DERIVATIVES AND GUNS}

\section{Derivatives and Guns Are Risk Management Tools}

Derivatives are bilateral contracts between two parties that are entered into in order to isolate and transfer market or credit risk from one party to another. Because derivatives are negotiated bilaterally, they can be tailor-made to suit specific hedging needs precisely; therefore, there are many variations on this basic pattern. Almost all derivatives, however, involve a bet in which gains and losses are calculated and settled periodically. Derivatives transactions offer investment opportunities (like gambling). One party will profit if the reference security or index goes up in value, and the other party will profit if it goes down in value. The transaction can provide risk-shifting opportunities (like insurance). Proponents of derivatives point out that these financial instruments reduce risk and increase transparency. Opponents refer to them as the stuff of fairytales like leprechauns with pots of gold. Since markets seem not to have learned from past disasters and investors should expect worse to come, betting on the leprechauns is arguably less risky than gambling on the soundness of derivatives finance.

Query: Why carry guns and derivatives if they are both as inherently dangerous as suggested? Why are they legally permitted? And if derivatives are such a threat, why does the size of bets on derivatives in the financial system continue to grow? The answers most likely lie in the balance of risk and reward. Myths and traditions on both sides need to be identified, researched, and evaluated to conduct an objective analysis.

In the United States of America, opinion polls consistently place firearm violence, commonly referred to as "gun violence," near the top of the public's list of concerns (Barry, et al., 2018). Firearm violence is violence committed with the use of a firearm or small arm (gun). This violence may be criminal or noncriminal. Examples of criminal gun violence include homicide and manslaughter (when one human causes

the death of another, except when ruled lawful, such as when justified by an affirmative defense, like insanity or self-defense), assault with a deadly weapon, and depending on the jurisdiction, suicide or attempted suicide. In the United States, suicide is far more common than homicide, and the suicide rate is increasing while the homicide rate is decreasing. As with other significant health problems, most cases of fatal firearm violence arise from large but low-risk subsets of the population; risk and burden of illnessare not distributed symmetrically. Examples of non-criminal gun violence may include accidental or 
unintentional death or injury. Compared with other industrialized nations, the United States has uniquely high mortality rates from firearm violence (Wintemute, 2015).

The human costs and financial burdens of firearm deaths and injuries are undeniably substantial. It is estimated that between 2012 and 2016, the global community suffered 1.4 million firearm-related deaths and over 2 million people living with firearm injuries (McEvoy \& Hideg, 2017; The Global Burden of Disease 2016 Injury Collaborators, 2018). "In addition to the thousands killed or injured, myriad families must also cope with the consequences of this violence. In terms of the financial toll, although the estimates vary, it is generally held that gun violence expenses - medical charges, loss of income, daily care/support, and criminal justice expenditures - cost the U.S. economy approximately \$229 billion annually" (Follman, et al., 2015). It is important to note that while data regarding military or para-military activities are included in these statistics along with civilians' actions, approximately 75 percent of the world's 875 million firearms are owned by civilians (United Nations Office on Drugs and Crime, 2015).

With these facts and figures in mind, we again question: If guns - and derivatives - are as dangerous as suggested, why they are legally permitted. Why, if guns are such a threat to the social system, does the size of gun markets continue to grow? And if derivatives pose such a significant threat to financial markets, why does the amount invested in derivatives continue to grow? The answers, or partial ones, might be found in examining some of the myths and pricing of risks in both domains.

\title{
In the United States of America, the Right to Own and Carry Guns and the Right to Engage in Option Derivatives Are Legally Protected
}

\author{
"We the People of the United States, in Order to form a more perfect Union, establish \\ Justice, insure domestic Tranquility, provide for the common defence, promote the general \\ Welfare, and secure the Blessings of Liberty to ourselves and our Posterity, do ordain and \\ establish this Constitution for the United States of America” (U. S. Const., pmb1.)
}

The U.S. Constitution's Preamble introduces everything, the articles and amendments, contained therein. It proclaims that the Constitution is adopted by "the People," for what reason, and identifies what is being adopted, i.e., "a single authoritative written text to serve as fundamental law of the land" (Chemerinsky and Paulsen (2021). And it anticipates that certain rights will be set forth that are to be enjoyed by "the People."

A right can be defined as "a thing one may legally or morally claim; the state of being entitled to a privilege or immunity or authority to act" (Allen, et al., 1990). Constitutional rights are those set forth, whether given or reserved, to individual entities. These rights may be within a state by its Constitution or nationally by the U.S. Constitution. In a legal context, there are two recognized central classes of entities that are the subject of rights, powers, and duties: (i) "Citizens"; and (ii) "Persons," who may be "natural" or "corporate."

\section{The Right to Bear Arms}

"A well regulated Militia, being necessary to the security of a free State, the right of the people to keep and bear Arms, shall not be infringed" (U.S. Const. amend. II).

Despite the tremendous societal changes in the United States of America and changes in its Armed Forces since the Amendment's ratification in 1791, there has been much and often heated debate over the proper interpretation of the Second Amendment. No more so evident than in matters relating to gun control and the right to keep and bear arms or so-called "gun rights." Although few modern-day U.S. civilians, if any, could reasonably expect it would be necessary to use personal firearms for militia duty, a vast number do "keep and bear Arms" for a variety of personal reasons, including self-defense, hunting, and other forms of recreational use. 
In 2008 and 2010, the U.S. Supreme Court handed down two significant decisions interpreting the scope of Second Amendment rights. In 2008, the Court issued a landmark decision in District of Columbia v. Heller. In Heller, the Court held that the Amendment's protections include an individual's right to keep and bear arms for traditionally recognized lawful purposes, such as self-defense within the home, within a federal enclave, and unconnected with service in a militia (District of Columbia v. Heller, 554 U.S. 570, (2008)). In Heller, the Court determined the constitutionality of the District of Columbia's ordinance that banned the possession of handguns and required residents to keep their lawfully-owned firearms, such as registered long guns, "unloaded and disassembled or bound by a trigger lock or similar device" unless they are located in a place of business or are being used for lawful recreational activities. The majority introduced its discussion of the challenged District of Columbia ordinance by asserting that "the inherent right of selfdefense has been central to the Second Amendment right." In a split, five-four decision, the often conservative-leaning Roberts Court concluded that the Second Amendment protects the "right of the people," an individual's right, (District of Columbia v. Heller, 2008, pp. 579-81, 592) and that "Arms" included "all instruments that constitute bearable arms, even those that were not in existence at the time of the founding," (District of Columbia v. Heller, 2008, p. 582) that the right to "keep" arms means the right to possess them, (District of Columbia v. Heller, 2008, p. 582), and the right to "bear" arms means the right to "carry a gun for a particular purpose - confrontation" (District of Columbia v. Heller, 2008, p. 584). The Court held that that the District of Columbia's "handgun ban amounts to a prohibition on an entire class of 'arms' that is overwhelmingly chosen by American society for that lawful purpose," and that the prohibition "extends, moreover, to the home, where the need for defense of self, family, and property is most acute" (Heller, 2008, pp. 628-629; Rosenthal, 2015, pp. 1195-1196). The majority added that this right does not include "dangerous and unusual weapons," underscoring that it had identified "these presumptively lawful regulatory measures only as examples" and that this list "does not purport to be exhaustive" (District of Columbia v. Heller, 2008, p. 627).

In 2010, the U.S. Supreme Court broadened the scope of its Second Amendment decisions in the case of McDonald v. City of Chicago (McDonald v. City of Chicago, 561 U.S. 742 (2010)). The Court held, in a 5-4 decision, that the protections afforded by the Second Amendment, encompassing gun-control laws, are fully applicable to state and local governments by application of the Fourteenth Amendment. (McDonald v. City of Chicago, 561 U.S. pp. 791, 839-858; Rosenthal, 2015, p. 1188).

\section{The Right to 'Keep and Bear' Financial Securities}

As previously discussed, the right to bear arms is a fundamental constitutional right. With that in mind, what if the right to 'keep and bear' or 'invest in and sell' financial securities, while not a fundamental right, is a derivative right? This interpretation would be significant because, like fundamental rights, derivative rights cannot be restricted without constitutionally lawful purposes.

The Commerce Clause of the U.S. Constitution (Article 1, Section 8, Clause 3) grants Congress the power "[t]o regulate Commerce with foreign Nations, and among the several States, and with the Indian tribes." The Founding Fathers, the framers of the Constitution, intended to preserve and protect existing rights, freeing their exercise from interference (Prentice, 1903); they did not anticipate that Congress might restrict the free intercourse of commerce. The Constitution, in all of its parts - Articles, Sections, and Clauses - looks to the security and free trade in persons and goods between the states, and the Commerce Clause specifically prohibits both Congress and the states from interfering with the freedom of intercourse and trade. (Tucker, 1803). As asserted by Alexander Hamilton (1787), "unrestrained intercourse between the States themselves will advance the trade of each."

Options are financial derivatives, contracts, which confer the right, but not the obligation, to buy or sell, depending on the type of contract, an underlying asset to the buyer at an agreed-upon price and date. Options are rights that form the basis for a wide range of option strategies designed for hedging, income, or speculation, and this right must be paid for, and this payment is known as the price or premium. The exercise of these rights form the basis for a wide range of option strategies designed for hedging, income, or speculation, and they have a price. Although there are many opportunities to profit with options, investors should carefully weigh the risks. Using the Black-Scholes model, also known as the Black-Scholes-Merton 
(B.S.M.) model, which is regarded as one of the best ways of determining the fair price of options, or other binomial approaches, can be used to calculate a theoretical value or option price on an underlying security. Hedgers, investors who seek to reduce the risk of an investment by making an offsetting investment, then look at the theoretical price to determine the fair market value of their protection. If financial options are not correctly priced, it may not be possible to differentiate between hedgers and speculators who are willing to take irresponsibly significant risks and sacrifice the safety of the principal in return for potentially significant gains.

Since the right to 'keep and bear Arms' is an option like the right to 'invest in and sell' financial options, we posit that they too must be priced appropriately - and that price or premium must include the benefits and the risks. If they are not correctly priced, it may not be possible to differentiate between law-abiding citizens with lawfully owned firearms and those individuals using their guns irresponsibly or criminals.

\section{REGULATION OF GUNS AND DERIVATIVES - WHAT DOES THE PAST AND FUTURE HOLD?}

\section{The Not-So-Wild West}

The term "the Old West" or "the Wild West" within the context of the United States of America conjures many images such as crusty prospectors, cattle ranchers, rustlers, banks, brothels and saloons, business and shop owners, and gun packing cowboys and outlaws shooting-up frontier towns (Jancer, 2018; Schwiger, 2019). And it is not uncommon to hear comparisons to the "Wild West" when violence erupts in our modern-day cities. However, as Aron (2016) noted: "Artists, historians and filmmakers alike have been guilty of creating a mythologized version of the U.S. expansion to the west." In fact, contrary to prevalent and widespread perception, the "Wild West" was not as wild as the myth created and perpetuated by the popular entertainment media. In fact, "literature based on actual history concludes that the civil society of the American West in the nineteenth century was not very violent" (DiLorenzo, 2021). Anderson and Hill (1979) confirm that even though "[t]he West . . is perceived as a place of great chaos, with little respect for property or life," research "indicates that this was not the case; property rights were protected, and civil order prevailed. Private agencies provided the necessary basis for an orderly society in which property was protected, and conflicts were resolved."

There were many reasons why the "Old West" was not as wild and dangerous as depicted in popular media. It is beyond the scope of this paper to examine all of them; however, there are two facts that significantly relate to our thesis. The first fact is that significant gun control was actually common. While frontier towns often permitted their residents to legally keep guns at home for self-protection and hunting, these towns usually barred anyone but law enforcement from carrying guns in public (Winkler, 2011). It has been concluded that the people of the Old West did not believe that owning a gun necessarily made one safe and that they realized that having fewer guns in populated areas led to less violence. Gun control was also desirable and enforced for economic reasons. The residents of these towns wanted limits on guns in public because they wanted to attract businesspeople and civilized folk. For example, few prospective store owners might choose to move to town if they were likely to be robbed when they took their daily earnings to the bank (Winkler, 2011). Jancer (2018) observed that "[t]he laws of Tombstone at the time required visitors, upon entering town to disarm, either at a hotel or a lawman's office," and the "[r]esidents of many famed cattle towns, such as Dodge City, Abilene, and Deadwood, had similar restrictions." This is not to say that the Old West was nonviolent. Rather, it is telling to observe that in the so-called Wild West, a strict form of gun control was desired and enforced, and gun violence in these towns was far rarer than commonly imagined. And the myth is often romanticized in order to support a false narrative.

The second fact about the so-called Wild West, which we believe supports our thesis, is another form of gun control - economic costs. In the Old West, the high cost of firearms and ammunition created an effective type of gun control (Worman, 2005). The cost of most guns was high compared to average wages and earnings. Acquiring a gun was typically a significant investment. While the cost of firearms in theOld

West varied, pistols and revolvers, rifles and carbines were relatively expensive in general. The cost of a revolver was $\$ 20$ to $\$ 30$, and a rifle was around $\$ 35$ to $\$ 40$. Furthermore, the cost of ammunition was an 
additional high cost. As noted by Trimble (2017), a "Remington 1877 catalog listed 1,000 rounds of .22 cartridges for $\$ 6$, while 56-50 rounds went for $\$ 40$. A Colt 1890 catalog listed 1,000 rounds of .22 rimfire for $\$ 5$, while .32 centerfire went for $\$ 11.32 "$ (Trimble, 2017). Although these costs may seem inexpensive in today's economy, a common laborer back then earned only a few dollars per week. For example, miners were well paid at $\$ 4$ per day in some instances, while cowhands may earn $\$ 30$ - $\$ 40$ per month (Trimble, 2017). Thus, for many people living in the Old West, purchasing a firearm was a considerable investment. And it is easy to imagine individuals saving a little every month, maybe for years, to have enough money to buy a gun. Accordingly, we conclude that most individuals who bought a gun at that time would have recognized and appreciated its value as a highly beneficial tool, and they no doubt would have weighed the benefits against the cost and would be seeking a premium.

For most people, life in the Old West was often harsh and challenging. Guns, e.g., pistols, rifles, and shotguns, were no doubt considered and treated as practical, valuable, and often much needed, multipurpose tools (Worman, 2005). A gun could, for example, be used to hunt and provide food as well as to fend off and, if necessary, kill dangerous animals that posed a threat to people and livestock. The loud report of most guns when fired could be used as an effective way to roundup herd animals such as cattle and horses and as a means of signaling other individuals. Furthermore, guns could be used to defend oneself and others from human threats such as bandits and rustlers. And while frontier lawmen usually carried and sometimes used firearms, their use was not always required to safely and successfully uphold the law. As Worman (2005) points out, Bertholomiew "Bat" Masterson has often been held out to have been one of the greatest of all frontier lawmen; however, he is known to have killed only two men while successfully maintaining public order.

Guns were frequently used in the Old West by many people, such as hunters and settlers, for selfprotection and, at times, their protection (Boorman, 2004). Some people also used guns to, legally or illegally, impose their will on others. However, contrary to current popular imagination, gun control is as old as the Old West, and bearing arms on the frontier was a heavily regulated business (Jancer, 2018). The awareness of firearms as an essential tool with the cost of acquisition and use appropriately valued along with gun controls - such as those put in place to protect persons and property and to promote economic stability and growth - were factors in lowering firearm deaths in the not so "Wild West" (Adler, 2015; Chapel, 2016).

\section{Deterrence}

Accessibility and use of guns are deeply ingrained in the United States of America, going back to European exploration and the country's founding onward. Gun control also has been part of this nation's social and political debates since its founding. The Second Amendment to the U.S. Constitution gives U.S. citizens the right to bear arms. Nevertheless, ever-increasing occurrences of firearm violence in this country have resulted in greater attention on gun control laws and the regulation of firearms. Recent studies indicate that close to half of the U.S. population (48\%) sees gun violence as a huge problem (Schaeffer, 2021). There is broad partisan agreement on some gun policy proposals, with roughly half of the country's population (53\%) favoring stricter gun laws. Most policy proposals, however, are divisive. For example, individuals living in U.S. rural areas typically favor more expansive gun access, while individuals living in urban areas prefer more restrictive policies. Attitudes toward gun violence also differ widely by race, ethnicity, community type, and political affiliation (Schaeffer, 2021).

There is data, however, that suggest that gun control laws are effective in curbing gun violence. Inone study, researchers grouped state gun control laws into extreme and lax gun control states and found that "comprehensive gun control legislation lowers the number of gun-related deaths anywhere between one to almost six per 100,000 individuals in those states that have the most extreme gun-related legislation" Kwon $\&$ Baack (2005). Many studies indicate, however, that socioeconomic variables and law enforcement factors also play significant roles in containing gun-related fatalities. Gun control laws and regulations alone are not responsible for lower crime rates (Mauser \& Holmes, (1992); Kwon \& Baack, 2005). And in recognizing that guns are valuable and popular tools, an important question must be answered: What is the most effective way of reducing gun violence while protecting people's legal right to keep and bear arms? 
The Old West and how people at that time viewed and dealt with firearms may give us some meaningful insights on how to limit gun violence in the present. In the Old West, guns were seen as valuable tools that people paid a hefty price to purchase; and it appears that the vast majority of people used guns for proper and legal purposes. It also appears that inhabitants of the Old West did not blame guns for the violence that occurred; they acknowledged that guns were tools that could be misused, resulting in death and injury as well as the loss and destruction of property. Humanitarian concerns and economic reasons led the residents of many towns in the old West to abide by strict gun control measures.

In the present day, there is general agreement that current gun laws in this country are not fully and effectively enforced (Kopan, 2016; Rivera, 2019). Evidence also does not conclusively show that existing laws, such as enhanced gun penalties, effectively deter crime and incapacitate dangerous criminals (Beale, 2002, p. 1681). Moreover, "there is massive evidence, which has accumulated for two centuries, that mandatory minimums foster circumvention by judges, juries, and prosecutors; reduce accountability and transparency; produce injustices in many cases; and result in wide unwarranted disparities in the handling of similar cases" (Tonry, 2009, p. 65).

The United States Centers for Disease Control and Prevention (CDC) looked at rates for gun homicides in the 50 most populous metropolitan areas in the U.S. and found that for 2009-2010, the top gun murder rate areas were, in order: New Orleans, Memphis, Detroit, Birmingham, St. Louis, Baltimore, Jacksonville, Kansas City, Philadelphia and Chicago (CDC, 2013). Six of those cities are in states with poor scores for their gun laws, while the other four get a " $\mathrm{C}$ " or better. Chicago, which placed last in the top 10, had a ban on handguns at the time. There is no discernible pattern among those cities, nor clear or convincing evidence in these statistics that shows more gun laws lead to more or less gun crime.

It would appear that both sides of the gun control debate are right and both are wrong. Based on the above CDC report, it can be concluded that gun control can actually add to gun violence, or not. Our conclusion is that there is more to this debate and the debate on how to reduce gun violence. For example, India, the country with the second-highest number of guns in the world after the U.S., with 46 million guns for over 1.25 billion people, does not figure even among the top five countries with the most shootings (Parker, et al., 2017). In America, it is often stated that the reason for our high rate of gun violence is the prevalence of guns on the streets; yet India, with the second-highest number of guns globally, is not considered a particularly violent place in terms of gun use. We need to look at stopping gun violence in a new way, as the old ways are clearly not working.

Like guns, derivatives are tools that can be used for both proper and improper purposes. Derivatives can be utilized as tools for either the defense and security of a business or unethical and criminal purposes. Are current U.S. laws enacted to regulate the use of derivatives and curb their misuse being fully and effectively enforced? How many individuals associated with the misuse of derivatives are fined or imprisoned?

We believe that the use and regulation of guns and derivatives can and should be looked at similarly. Both are valuable tools that can be used for good purposes such as defending oneself or others or for destructive purposes such as robbing others of their wealth. The value of an individual's life cannot be priced. When derivatives are misused, however, they too can destroy lives and businesses - how should that be priced? If this question could be answered conclusively, it could go a long way toward preventing significant emotional harm and economic loss for countless individuals and families.

\section{Regulation of Firearms - The Relevance of the Second Amendment: Ideological Origins and Boundaries}

The Second Amendment to the U.S. Constitution is the only provision contained in the Bill of Rights that includes a preamble: "A well regulated Militia, being necessary to the security of a free State, the right of the people to keep and bear Arms, shall not be infringed" (U.S. CONST. amend. II). The relationship between the Amendment's preamble and its operative clause is not obvious, resulting in a challenging interpretive legacy. This legacy has critical implications for the regulation of firearms in this country.

When the U.S. Supreme Court deliberated and decided the District of Columbia v. Heller case, it had to interpret the meaning of the Second Amendment's preamble. The Court held that the preamble is a 
"prefatory" clause to the Second Amendment's remaining "operative" clause." The Court found that "the former does not limit the latter grammatically, but rather announces a purpose." Asserting that, in the Framing era, the preamble would not have been understood to "limit or expand the scope of the operative clause," but it instead merely "announce[d] the purpose for which the right was codified: to prevent elimination of the militia" (District of Columbia v. Heller, 2008, pp. 578, 599; Rosenthal, 2015, p. 1188). "Putting all of these textual elements together," the Court's majority found "that they guarantee the individual right to possess and carry weapons in case of confrontation." The Court stated that "[t]his meaning is strongly confirmed by the historical background of the Second Amendment," and explained that it "look[ed] to this because it has always been widely understood that the Second Amendment, like the First and Fourth Amendments, codified a pre-existing right."

Based on the Second Amendment's text and historical analysis, the U.S. Supreme Court held that the Second Amendment confers an individual right to possess and carry weapons in case of confrontation. The Heller Court's holding did not, however, go so far as to state or even suggest that this right is without limitation. The majority explained that "we do not read the Second Amendment to protect the right of citizens to carry arms for any sort of confrontation, just as we do not read the First Amendment to protect the right of citizens to speak for any purpose" (District of Columbia v. Heller, 2008, p. 626). The Heller Court stated, albeit in dicta, that the Second Amendment "[i]s not a right to keep and carry any weapon whatsoever in any manner whatsoever and for whatever purpose" (District of Columbia v. Heller, 2008, p. 626). The majority also expressly stated:

Although we do not undertake an exhaustive historical analysis today of the full scope of the Second Amendment, nothing in our opinion should be taken to cast doubt on longstanding prohibitions on the possession of firearms by felons and the mentally ill, or laws forbidding the carrying of firearms in sensitive places such as schools and government buildings, or laws imposing conditions and qualifications on the commercial sale of arms.

The Heller Court stated that it had "identif[ied] these presumptively lawful regulatory measures only as examples; our list does not purport to be exhaustive" (Rosenthal, 2015, pp. 1193-1194). When the U.S. Supreme Court subsequently applied the incorporation doctrine, concluding in the case of McDonald $v$. City of Chicago that the Second Amendment applies to state and local governments through the Due Process clause of the Fourteenth Amendment, four of the five Justices in the majority referred to the Court's prior discussion in Heller of presumptively lawful regulations. The majority stated: "We repeat those assurances here. Despite municipal respondents' doomsday proclamations, incorporation does not imperil every law regulating firearms" (McDonald v. City of Chicago, 2010, p. 786).

The Heller Court and the McDonald Court correctly recognized that this country's Founders wished to protect its citizens from being disarmed entirely because the militia of the Founding era was composed of ordinary citizens who needed to be able to bear arms to defend the country and themselves from threats. This included the threat of a potentially tyrannical federal government. James Madison stated that: "Besides the advantage of being armed, which the Americans possess over the people of almost every other nation... (where) ...the governments are afraid to trust the people with arms" (Madison, Federalist Papers \#46). The constitutional right to keep and bear arms was established to give U.S. citizens a protected right to have any kind of ordinary firearm, anywhere they wanted. The Second Amendment was written and adopted with the intent to ensure public safety. The Founders did not, however, seek to prevent governmental regulation of guns and gun owners. Nothing in the Second Amendment's language was thought to preventregulation, including gun control. Gun control is as much a part of the Second Amendment as is the right to keep and bear arms (Walker, 2015). Forms of gun regulation that some or even many might argue, at the beginning of the twenty-first century, as overly burdensome are thus constitutional.

In the face of continued Second Amendment debate and legal challenges, as noted by Ruben (2020), "Heller's handgun holding, and the notion of weapon popularity on which it rests is problematic for many reasons. It is important to note that the Heller Court's discussion of presumptively lawful gun control was dicta - unnecessary to the Court's holding in the case on review. Moreover, that dicta appears to create a 
presumption that can, presumably, be rebutted (Rosenthal, 2015, pp. 1194-1195; Ruben \& Blocher, 2018). The nature and obscurity of the Court's underlying language, about presumptions and longstanding regulations, has given rise to a split — whether it qualifies as holding or dicta — which has given rise to some existing circuit splits as well. This split, or disagreement, is in part because it can be notoriously difficult to separate dicta from holding (Goodhart, 1930). And such a task "presents unexpected difficulties in interpretation" (Levinson, S., 1989). Furthermore, in its Heller decision, the Court refused to adopt any level of judicial scrutiny against which a gun-control law could be tested to determine if it could withstand legal challenge. The majority did, however, reject the view that a challenged regulation need only have a

rational basis to survive challenge. The majority also declined to adopt the interest-balancing test advocated by Justice Stephen Breyer in his dissent (District of Columbia v. Heller, 2008, pp. 628, 634$635)$.

The preamble to the Second Amendment has long been at the center of an interpretive firestorm, and we must still try to figure out what might be suggested by guaranteeing to 'the people the right to keep and bear arms". The American public is polarized, and now, more than ever, there is a sense of urgency arising from the debate over gun control. "Disagreements over gun legislation reveal disparate perceptions of American society that rest upon, or inspire, dissimilar interpretations of the Second Amendment" (Blocher \& Miller, 2016).

As Blocher and Miller (2016, p. 296) note, "The boundaries of the Second Amendment do not coincide with the boundaries of gun control. The Amendment does not reach, let alone prohibit, all direct burdens imposed by gun control." Adding "Conversely, it might apply to - and could invalidate - some incidental burdens imposed by civil suits or other gun-neutral laws of general applicability." As Dorf observed, "the potential for contestation over the Second Amendment's final word: "infringed." When does the application of a gun-neutral law infringe the right? In that deceptively simple question lurk important future debates over the Second Amendment, the Constitution, and law itself" (Dorf, 2016, p. 112).

Adding to the complexity and perhaps uncertainty is that the matter may be more theoretical than practical Nonetheless, for lower courts, as noted by the United States Court of Appeals, Tenth Circuit, we are "bound by Supreme Court dicta almost as firmly as by the Courts' outright holdings..." (Bonidy v. U.S. Postal Service, 2015). Thus, the lower courts, including the U.S. Courts of Appeals, may decline to extend or elaborate upon the higher Court's dicta and thus offer some additional judicial clarification as to the constitutional scope of the Second Amendment with respect to gun rights and regulation.

\section{Regulation of Financial Securities}

Financial markets have been likened to the nostalgic and somewhat fairytale Wild West. A place where anything could happen at any time, with a get-rich-quick crowd with a voracious appetite for risk and acting with reckless abandon and rampant speculation. Nevertheless, financial markets also include prudent Wall Street professionals acting with vigilant, thoughtful restraint and cautious, inexperienced, small investors, all of whom seek to maximize returns while protecting themselves and others against imprudent risks (DeCambre \& Oh, 2020). And just as bearing arms on the frontier was a heavily regulated business, and thus gun control is as old as the Old West (Jancer, 2018), our financial markets are significantly regulated. The Commerce Clause, in Article I, section 8, of the U.S. Constitution, grants Congress the authority "[t]o regulate Commerce with foreign Nations, and among the several States, and with the Indian tribes." (U.S. Const. art. I, § 8, cl. 3). Both Congress and the U.S. Supreme Court, however, have struggled to define the limits of that authority. Nevertheless, it has always been understood that some limit exists beyond which Congress may not go (Barnett, 2001, p. 146). Since its 1937 holding in N.L.R.B. v. Jones \& Laughlin Steel Corporation, the U.S. Supreme Court has been deferential to congressional claims of authority to regulate commerce. Nevertheless, even as it allowed Congress to exercise expansive powers over the national economy, the Court declared firmly:

The authority of the federal government may not be pushed to such an extreme as to destroy the distinction, which the commerce clause itself establishes, between commerce "among the several States" and the internal concerns of a State. That distinction between what is 
national and what is local in the activities of commerce is vital to the maintenance of our federal system (N.L.R.B. v. Jones \& Laughlin Steel Corp., 1937, p. 907).

There is a balance at issue - Congress's powers over interstate commerce must be essentially limited unless the states are to lose control over their internal commercial spheres (Corwin (1987). In Schechter Poultry Corp., (1935), Chief Justice Hughs, writing for the Court, declared:

The congressional authority to protect interstate commerce from burdens and obstructions is not limited to transactions which can be deemed to be an essential part of a 'flow' of interstate or foreign commerce. Burdens and obstructions may be due to injurious action springing from other sources. The fundamental principle is that the power to regulate commerce is the power to enact 'all appropriate legislation' for its 'protection or advancement'; to adopt measures 'to promote its growth and insure its safety'; 'to foster, protect, control, and restrain.' Although activities may be intrastate in character when separately considered, if they have such a close and substantial relation to interstate commerce that their control is essential or appropriate to protect that commerce from burdens and obstructions, Congress cannot be denied the power to exercise that control. Undoubtedly the scope of this power must be considered in the light of our dual systemof government and may not be extended so as to embrace effects upon interstate commerce so indirect and remote that to embrace them, in view of our complex society, would effectually obliterate the distinction between what is national and what is local and create a completely centralized government. If the commerce clause were construed to reach all enterprises and transactions which could said to have an indirect effect upon interstate commerce, the federal authority would embrace practically all the activities of the people, and the authority of the state over its domestic concerns would exist only by sufferance of the federal government.

The exercise and the restraint of Congressional authority can be seen in the Securities Act of 1933, also known as the 1933 Act, the Securities Act, the Truth in Securities Act, the Federal Securities Act, and the '33 Act. The Securities Act of 1933 prohibits the offer and sale of unregistered, nonexempt securities. But there are exemptions from the registration requirement. For example, Section 3(b) authorizes the U.S. Securities and Exchange Commission ("S.E.C."), by means of rules and regulations, to add any class of securities to the securities exempted as provided in the ' 33 Act if the S.E.C. finds that the enforcement of the ' 33 Act is not necessary in the public interest and for the protection of investors by reason of the small amount involved or the limited character of the public offering, subject to the limitation that the aggregate amount at which the issue is offered to the public cannot exceed $\$ 5,000,000$.

\section{Deterrence}

There is an adage, perhaps a truism, that the law never made anything perfect. Financial markets law, which includes securities/capital markets law, is an imperfect yet necessary tool for the effective regulation and supervision of the whole financial services sector (Johnson, 2010; Packin, 2013).

After the Great Depression and then again the Great Recession, considerable legislative attention was given to shaping environmental factors in which risk-related decisions in financial institutions are made (Packin, 2013). Regulation can help actors make better, less risky choices. As one highly respected law professor observed, "[s]elf-preservation instincts, market forces, personal morality, and governmental regulation combine to control unreasonably dangerous actions" (Sugarman, 1985, p. 561).

The economic crisis of the 1920s and 1930s ended years of a laissez-faire policy and led to intensive efforts by the U.S. federal government to regulate business (Keller,1988). The Securities Act of 1933

(Securities Act) and the Securities Exchange Act of 1934 (Exchange Act) were crucial components of the regulator safeguards put in place during the Great Depression and the legislation that had the most significant effect on the securities market (Keller, 1988). Nearly eight decades later, in the aftermath of the 
2008 financial crisis, Congress passed the Dodd-Frank Wall Street Reform and Consumer Protection Act of 2010 (Dodd-Frank Act) which enhanced the U.S. Commodity Futures Trading Commission's (C.F.T.C.'s) regulatory authority to oversee the hundred trillion dollar swaps market. The purpose of the Dodd-Frank Act was to restructure the financial regulatory system to restore public confidence following the 2008 financial crisis and to prevent another crisis from occurring (Murdock, 2011). There is continued optimism that new legislation, regulation, and oversight will provide, as Packin pronounced, "incentives that will not only help reduce excessive risk-taking but may even raise social responsibility awareness, all while not compromising financial institutions' legal and financial responsibilities" (Packin, 2013, pp. 419, 420; Pope \& Lee, 2013).

There are, however, skeptics who correctly note that many were wrong in thinking that the Securities Act might make it possible to "prevent a recurrence of the scandals which have brought many financiers into disrepute" or "eliminate wholly unsound capital structures." As Douglas and Bates, there is nothing in the Securities Act that would control the American public's speculative craze, eliminate wholly unsound capital structures, prevent tyrannical management from playing wide and loose with scattered minorities, or "which would prevent a new pyramiding of holding companies violative of the public interest and all canons of sound finance" (Douglas \& Bates, 1933, p. 171). "All the [Securities] Act pretends to do is to require the 'truth about securities' at the time of issue, and to impose a penalty for failure to tell the truth. Once it is told, the matter is left to the investor. But even the whole truth cannot be told in such simple and direct terms as to make investors discriminating. A slow educational process must precede that" (Douglas \& Bates, 1933, pp. 171-172).

Furthermore, there is nothing in the other four principal federal regulatory initiatives regarding derivative securities, i) the Future Trading Act of 1921, ii) the Commodity Exchange Act of 1936, iii) the Commodity Futures Trading Commission Act of 1974, and iv) the Futures Trading Practices Act of 1992, which would make it possible to prevent a recurrence of the scandals which have brought many financiers into disrepute, eliminate wholly unsound capital structures which are violative of the public interest and all canons of sound finance" Romano (1997).

Former Federal Reserve Chairman Alan Greenspan, a long-time cheerleader for deregulation, wrotein his 2007 memoir: "[A]ssisted by the wave of deregulation since the mid-1970s, today's U.S. economy remains the most competitive large economy in the world, and American culture still exhibits much of the risk-taking and taste for adventure of the country's earlier years. More than a century after Frederick Jackson Turner declared in 1893 that the frontier was closed, Americans reveled in stories of the exploits of the free-spirited cowboys who, following the Civil War, manned the cattle drives up the Chisholm Trail from Texas to the rail depots of Kansas" (Greenspan, 2007, p. 79). But on October 23, 2008, Greenspan acknowledged, during a House Oversight and Government Reform Committee hearing, that the immense and largely unregulated business of spreading financial risk widely through the use of types derivatives (primarily credit default swaps) had gotten out of control, created trillions of dollars of liabilities and added to the havoc of the financial crisis of 2007-2008. Many economists considered this global financial crisis to have been the most severe financial crisis since the Great Depression. The Great Recession that followed brought Wall Street's giants to their knees and cost many ordinary people their jobs, their savings, their homes, or all three. Greenspan went on to proclaim: "Those of us who have looked to the self-interest of lending institutions to protect shareholders' equity (myself especially) are in a state of shocked disbelief." He stated his regret over opposing regulatory curbs on certain types of financial derivatives, admitting, "I made a mistake in presuming that the self-interests of organizations, specifically banks and others, were such that they were best capable of protecting their own shareholders and their equity in the firms." During the feisty exchange, Greenspan told the committee that "[t]his modern risk-management paradigm held sway for decades," and "[t]he whole intellectual edifice . . . collapsed in the summer of last year." He acknowledged: "Yes, I've found a flaw. I don't know how significant or permanent it is. But I've beenvery distressed by that fact" (The Financial Crisis and the Role of Federal Regulators, 2008).

The point is not that unregulated markets are entirely to blame for the systematic mistakes and private errors that were the primary cause of the financial crisis. The lesson to be learned is that it is vital not to lose sight of the real benefits of derivatives, and all parties involved will hopefully make wiser decisions in 
the future. "[B]ecause derivatives often are used to reduce or avoid the costs of financial regulation," and their use can sometimes result in some harm to society, "the question of whether increased derivatives use is 'good' or 'bad' depends on the particular use" (Partnoy, 1997).

\section{SUMMARY AND CONCLUSION}

It has been astutely observed that "the orthodox positions in America's ongoing gun debate oscillate between 'Any gun law is a retreat away from the lack of government interference that made this country great' and 'If we don't regulate firearms, we'll end up like the Wild West,' robbing both sides of ahistorical bedrock of how and why gun law developed as America expanded Westward" (Jancer, 2018).

Ongoing debate about the pricing, costs (including risks), and regulation of financial derivatives and its similarity to the debate about guns lead us to raise a similar observation: 'Any law restraining free trade is a retreat away from the lack of government interference that made this country great' and 'If we don't regulate the financial markets and the tools used therein, we'll end up like the [mythical] Wild West,' robbing both sides of a historical bedrock of how and why the laws and regulations governing financial markets developed as America expanded' and became one of the world's largest and most influential economies.

We suggest that the gun and financial derivatives domains can both be explained using concrete and theoretical approaches that are commonly applied to calculate the costs and pricing of options to determine the fair market value of their protection. Gun owners and financial investors both seek to minimize costs and maximize benefits. "Decision-makers do not make risky decisions in a vacuum, but in anenvironment where multiple factors can influence their decisions. Such factors include cognitive-related biases and group-related biases" (Packin, 2013, p. 419). This is true of options traders and gun carriers.

The last few years have demonstrated the need for stricter regulation, particularly regulation concerning risk-taking, in relation to both financial securities and guns. While both can be significantly valuable tools, they can also be "weapons of mass destruction" that impose externalities on society. In light of those externalities, laws and regulations used to identify, monitor, and mitigate risks are essential and legal intervention to regulate the risk of such externalities is justified based on standard economic theory. Regulation concerning risk-taking does carry high economic and social costs and should be carefully created (Packin, 2013, pp, 424, 481).

Since the right to keep and bear arms is an option like the right to invest in and sell financial options, we posit that they too must be appropriately priced - and that price or premium must include the benefits and the costs. If guns are not correctly priced, it may be difficult to differentiate between law-abiding citizens with lawfully owned firearms and those individuals using their guns irresponsibly or illegally. If financial options are not correctly priced, it may not be possible to differentiate between hedgers and speculators who are willing to take irresponsibly large risks and sacrifice the safety of the principal in return for potentially significant gains.

\section{REFERENCES}

Adler, D. (2015). Guns of the American West. New York: Skyhorse Publishing.

Allen, R.E., Fowler, H.W., \& Fowler, F.G. (1990). The Concise Oxford dictionary of current English. Oxford: Clarendon Press.

Anderson, T., \& Hill, P.J. (1979). An American Experiment in Anarcho-capitalism: The Not So Wild, Wild West. Journal of Libertarian Studies, 3(1), 9-29. Retrieved June 8, 2021, from https://cdn.mises.org/3_1_2_0.pdf

Aron, S. (2016). The History of the American West Gets a Much-Needed Rewrite. Retrieved June 8, 2021, from https://www.smithsonianmag.com/history/history-american-west-gets-much-neededrewrite-180960149/

Baker, J.J. (1992). Second amendment message in Los Angeles. American Rifleman, pp. 32-34.

Barnett, R.E. (2001). The Original Meaning of the Commerce Clause. The University of Chicago Law 
Review, 68(1), 101-147.

Barry, C., Webster, D., Stone, E., Crifasi, C., Vernick, J., \& McGinty, E. (2018). Public Support for Gun Violence Prevention Policies Among Gun Owners and Non-Gun Owners in 2017. American Journal of Public Health, 108(7), 878-881. Retrieved June 8, 2021, from https://ajph.aphapublications.org/doi/pdfplus/10.2105/AJPH.2018.304432

Beale, S. (2002). The Unintended Consequences of Enhancing Gun Penalties: Shooting Down the Commerce Clause and Arming Federal Prosecutors. Duke Law Journal, 51(5), 1641-1681.

Bjerregaard, B., \& Lizotte, A.J. (1995). Gun Ownership and Gang Membership. Journal of Criminal Law and Criminology, 86(1), 37-58.

Blocher, J., \& Miller, A. (2016). What Is Gun Control? Direct Burdens, Incidental Burdens, and the Boundaries of the Second Amendment. University of Chicago Law Review, 83(1), 295-355.

Bonidy v. U.S. Postal Service, 790 F.3d 1121 (10th Cir. 2015).

Boorman, D. (2004). Guns of the Old West: An Illustrated History. Connecticut: The Lyons Press.

Buffett, W. (2002). 2002 Chairman's Letter, Berkshire Hathaway Inc. Retrieved June 8, 2021, from https://www.berkshirehathaway.com/letters/2002pdf.pdf

Buffett, W., \& Munger, F. (2016). 2016 Berkshire Hathaway Annual Meeting. Berkshire Hathaway, Inc.

Retrieved June 8, 2021, from https://buffett.cnbc.com/2016-berkshire-hathaway-annual-meeting/

Chapel, C.E. (2016). Guns of the Old West. Texas: Normanby Press.

Chemerinsky, E., \& Paulsen, M.S. (2021). Common Interpretation: The Preamble. National Constitution Center, Interactive Constitution. Retrieved May 21, 2021, from https://constitutioncenter.org/interactive- constitution/interpretation/preamble-ic/interps/37

Cohn, E.G., \& Farrington, D.P. (1994). Who Are the Most Influential Criminologist in the EnglishSpeaking World? British Journal of Criminology, 34(2), 204-225.

Cook, P.J., \& Ludwig, J. (2000). Gun Violence: The Real Costs. Oxford University Press. ISBN: 9780195137934. OCLC 45580985

Corwin, E. (1987). Corwin on the Constitution Volume Two: The Judiciary. Ithaca and London: Cornell University Press, 353.

Dastagir, A. (2017). The gun debate isn't about what you think. Retrieved June 8, 2021, from https://www.usatoday.com/story/news/nation/2017/10/04/gun-culture/724571001/

DeCambre, M., \& Oh, S. (2020). It's like the Wild West with 'get-rich-quick crowd' vs. Wall Street pros, but it's too easy to blame retail investors for 'rampant speculation'. MarketWatch. Retrieved May 21, 2021, from https://www.marketwatch.com/story/its-like-the-wild-west-in-the-stock-marketwith-the-get- rich-crowd-vs-wall-st-pros-but-its-too-easy-to-blame-retail-investors-for-rampantspeculation-2020-06-13

DiLorenzo, T. (2010). The Culture of Violence in the American West: Myth versus Reality. The Independent Review, 15(2), 227-239. Retrieved June 8, 2021, from

http://www.jstor.org/stable/24562364

District of Columbia v. Heller, 554 U.S. 570. (2008).

Dorf, M. (2016). Incidental Burdens and the Nature of Judicial Review. University of Chicago Law Review, 83(1).

Douglas, W., \& Bates, G. (1933). The Federal Securities Act of 1933. Yale Law Review, 43(2), 171-172.

Follman, M., Lurie J., Lee, J., \& West, J. (2015). The True Cost of Gun Violence in America: The data the N.R.A. doesn't want you to see. Mother Jones. Retrieved May 21, 2021, from https://www.motherjones.com/politics/2015/04/true-cost-of-gun-violence-in-america/

Garbarino, J., Bradshaw, C.P., \& Vorrasi, J.A. (2002). Mitigating the effects of gun violence on children and youth. The Future of Children, 12, 73-85. doi:10.2307/1602739

Garner, B.A., \& Black, H.C. (2009). Black's law dictionary (9th ed.). St. Paul, MN: West.

Goodhart, A. (1930). Determining the Ratio Decidendi of a Case. The Yale Law Journal, 40(2), 161-183.

Greenspan, A. (2002). Alan Greenspan: Finance - United States and global. Remarks by Mr. Alan Greenspan, Chairman of the Board of Governors of the US Federal Reserve System, at the Institute of International Finance, New York, (via videoconference). Retrieved June 2, 2021, from 
https://www.bis.org/review/r020423b.pdf

Greenspan, A. (2007). The Age of Turbulence: Adventures in a New World. New York, NY: The Penguin Press.

Hamilton, A. (1787). Federalist No. 11 "The Utility of the Union in Respect to Commercial Relations and a Navy". The Avalon Project, Lilian Goldman Law Library, Yale University. Retrieved May 21, 2021, from https://avalon.law.yale.edu/18th_century/fed11.asp

Jancer, M. (2018). Gun Control Is as Old as the Old West: Contrary to the popular imagination, bearing arms on the frontier was a heavily regulated business. Smithsonian Magazine. Retrieved May 22, 2021, from https://www.smithsonianmag.com/history/gun-control-old-west-180968013/

Karp, A. (2018). Global Firearms Holdings. Geneva, Switzerland: Small Arms Survey, Graduate Institute of International and Development Studies.

Kassirer, J. (1991). Firearms and the killing threshold. (Editorial). New England Journal of Medicine, 325(23), 1647-1651.

Keller, E. (1988). Introductory Comment: A Historical Introduction to the Securities Act of 1933 and the Securities Exchange Act of 1934. Ohio State Law Journal, 49(2), 329-352.

Kellerman, A.L., \& Rivara, F.P. (1992). Suicide in the Home in Relation to Gun Ownership. The New England Journal of Medicine, 327(7), 467-472.

Kleck, G. (1997). Targeting Guns: Firearms and Their Control. New Jersey: Transaction Publishers.

Kleck, G. (2004). Measures of Gun Ownership Levels of Macro-Level Crime and Violence Research. Journal of Research in Crime and Delinquency, 41(1), 3-36.

Koehler, C. (2011). The Relationship between the Complexity of Financial Derivatives and Systemic Risk. Working Paper, pp. 10-11.

Kopan, T. (2016). Why even the gun laws that exist don't always get enforced. Retrieved May 21, 2021, from https://www.cnn.com/2016/01/09/politics/obama-executive-orders-gun-controlenforcement-gap/index.html

Kwon, I., \& Baack, D. (2005). The Effectiveness of Legislation Controlling Gun Usage: A Holistic Measure of Gun Control Legislation. The American Journal of Economics and Sociology, 64(2), 533-547.

Kwon, I., Scott, B., Safranski, S., \& Bae, M. (1997). The Effectiveness of Gun Control Laws: Multivariate Statistical Analysis. The American Journal of Economics and Sociology, 56(1), 41-50.

Levinson, S. (1989). The Embarrassing Second Amendment. The Yale Law Journal, 99(3), 637-659.

Lund, N., \& Winkler, A. (2015). The Second Amendment (September 18, 2015). National Constitution Center, Interactive Constitution; George Mason Legal Studies Research Paper No. LS 15-23. Retrieved May 22, 2021, from https://www.law.gmu.edu/assets/files/publications/working_papers/LS1523.pdf

Mauser, G.A., \& Holmes, R.A. (1992). An Evaluation of the 1977 Canadian Firearm Legislation. Evaluation Review, 16(6), 603-617.

McDonald v. City of Chicago, 561 U.S. 742, 791. (2010).

McEvoy, C., \& Hideg, G. (2017). Global Violent Deaths 2017. Geneva, Switzerland: Small Arms Survey, Graduate Institute of International and Development Studies.

Metzl, J.M. (2018). Repeal the Dickey Amendment to Address Polarization Surrounding Firearms in the United States. American Journal of Public Health, 108(7), 864-865. Retrieved May 21, 2021, from https://doi.org/10.2105/AJPH.2018.304461

National Public Radio. (2015). Ex-Rep. Dickey Regrets Restrictive Law on Gun Violence Research. Retrieved February 6, 2021, from https://www.npr.org/2015/10/09/447098666/ex-rep-dickeyregrets- restrictive-law-on-gun-violence-research

Murdock, C. (2011). The Dodd- Frank Wall Street Reform and Consumer Protection Act: What Caused the Financial Crisis and Will Dodd-Frank Succeed in Preventing Future Crises? Southern Methodist University Law Review, 64(4), 1242-1328.

National Research Council (2004). Executive Summary. In C.F. Wellford, J.V. Pepper, \& C.V. Petrie, Firearms and Violence: A Critical Review. Washington, DC: National Academies Press. ISBN: 
978-0-309-09124-4

National Labor Relations Board (N.L.R.B.) v. Jones \& Laughlin Steel Corp., 301 U.S. 1. (1937).

Johnson, K. (2010). From Diagnosing the Dilemma to Divining a Cure: Post-Crisis Regulation of Financial Markets. Seton Hall Law Review, 40(4), 1299-1321.

Packin, N. (2013). It's (Not) All About the Money: Using Behavioral Economics to Improve Regulation of Risk Management in Financial Institutions. University of Pennsylvania Journal of Business Law, 15(2), 419-482.

Parker, K., Horowitz, J., Igielnik, R., Oliphant, J., \& Brown, A. (2017). America's Complex Relationship With Guns. Washington, DC: Pew Research Center. Retrieved June 8, 2021, from https://www.pewresearch.org/social-trends/2017/06/22/americas-complex-relationship-with-guns/

Partnoy, F. (1997). Financial Derivatives and the Costs of Regulatory Arbitrage. Journal of Corporation Law, 22, 211-256.

Pope, K., \& Lee, C. (2013). Could the Dodd-Frank Wall Street Reform and Consumer Protection Act of 2010 be Helpful in Reforming Corporate America? An Investigation on Financial Bounties and Whistle- Blowing Behaviors in the Private Sector. Journal of Business Ethics, 112(4), 597-607.

Prentice, E.P. (1903). The Origin of the Right to Engage in Interstate Commerce. Harvard Law Review, $17(1), 20-40$.

Rajan, R.G. (2006). Has Financial Development Made the World Riskier? European Financial Management, 12(4), 499-533. doi:10.1111/j.1468-036X.2006.00330.x

Romano, R. (1997). The Political Dynamics of Derivative Securities Regulation. Yale Journal on Regulation, 14(2), 279- 406. Retrieved May 22, 2021, from https://digitalcommons.law.yale.edu/yjreg/vol14/iss2/2

Rivera, A. (2019). A Call to Action: Policy Proposals to Ameliorate Gun Violence in the U.S. [The Trinity Papers (2011 - present), Hartford, CT: Trinity College Digital Repository. Retrieved February 6, 2021, from https://digitalrepository.trincoll.edu/trinitypapers/72

Rosenthal, L. (2015). The Limits of Second Amendment Originalism and the Constitutional Case for Gun Control. Washington University Law Review, 92(5), 1187-1259.

Rostron, A. (2018). The Dickey Amendment on Federal Funding for Research on Gun Violence: A Legal Dissection. American Journal of Public Health, 108(7), 865-867.

Ruben, E. (2020). An Unstable Core: Self-Defense and the Second Amendment. California Law Review, $108(1), 63-106$.

Ruben, E., \& Blocher, J. (2018). From Theory to Doctrine: An Empirical Analysis of the Right to Keep and Bear Arms After Heller. Duke Law Journal, 67(7), 1433-1509.

Schaeffer, K. (2021). Key Facts about Americans and guns, F.A.C.T.A.N.K. Pew Research Center. Retrieved May 24, 2021, from https://www.pewresearch.org/fact-tank/2021/05/11/key-factsabout-americans-and-guns/

Schechter Poultry Corp. v. United States, 55 Sup. Ct. 837, 850, 851. (1935).

Schweiger, C. (2019). History of the American West: The Reality of Guns and the Wild West. Retrieved May 24, 2021, from https://medium.com/@chipschweiger/history-of-the-american-west-thereality-of- guns-and-the-wild-west-151af6e 0a055

S. Hrg. 113-96, Volume 1: JPMorgan Chase Whale Trades: A Case History of Derivatives Risks and Abuses: Hearing before the Permanent Subcommittee on Investigations, of the Senate Committee on Homeland Security and Governmental Affairs, 113th Cong. ${ }^{\text {st }}$. (2013). Retrieved May 20, 2021, from https://www.govinfo.gov/content/pkg/CHRG-113shrg80222/html/CHRG$113 \mathrm{shrg} 80222 . \mathrm{htm}$

Schechter Poultry Corp. v. United States, 295 U.S. 495, 55 Sup. Ct. 837. (1935).

Schumaker, E. (2019). Congress agrees on historic deal to fund \$25 million in gun violence research. Retrieved May 21, 2021, from https://abcnews.go.com/Health/congress-approves-unprecedented25- million-gun-violence-research/story?id $=67762555$

Sugarman, S. (1985). Doing Away with Tort Law. California Law Review, 73(3), 555-664. The Constitution of the United States, preamble. 
The Constitution of the United States. amend. II.

The Financial Crisis and the Role of Federal Regulators: U.S. House of Representatives Committee on Oversight and Government Reform 110th Cong. (2008). Testimony of Alan Greenspan. Retrieved May 23, 2021, from https://www.govinfo.gov/content/pkg/CHRG-110hhrg55764/pdf/CHRG110hhrg55764.pdf

The Global Burden of Disease 2016 Injury Collaborators. (2018). Global Mortality. Firearms, 1990-2016. Journal of the American Medical Association, 320(8), 792-814.

Tonry, M. (2009). The Mostly Unintended Effects of Mandatory Penalties: Two Centuries of Consistent Findings. Crime and Justice, 1(38), 65-114.

Trimble, M. (2017). Was Ammunition Expensive? True West Magazine. Retrieved May 21, 2021, from https://truewestmagazine.com/article/was-ammunition-expensive/

Tucker, St., G. (1803). View of the Constitution of the United States with Selected Writings. (Ed.), Clyde N. Wilson (Indianapolis: Liberty Fund, Inc.).

United Nations Office on Drugs and Crime. (2015). U.N.O.D.C. Study on Firearms 2015. Vienna: United Nations Office on Drugs and Crime.

United States Centers for Disease Control and Prevention. (2013). Firearm Homicides and Suicides in Major Metropolitan Areas - United States, 2006-2007 and 2009-2010. Morbidity and Mortality Weekly Report, 62(30), 597-602.

U.S. Congress. (1933). United States Code: Securities Act of 1933, Pub. L. No. 73-22, 48 Stat. 74 (1933) (codified as amended at 15 U.S.C. $\S$ 77a-77aa (1982 \& Supp. IV 1986)).

Walker, D. (2016). Necessary to the Security of Free States: The Second Amendment as the Auxiliary Right of Federalism. American Journal of Legal History, 56(4), 365-391.

Wintemute, G. (2015). The epidemiology of firearm violence in the twenty-first century United States. Annual Review of Public Health, 36(1), 5-19. Retrieved May 21, 2021, from https://pubmed.ncbi.nlm.nih.gov/25533263/

Worman, C.G. (2005). Gunsmoke and Saddle Leather: Firearms in the Nineteenth-Century American West. Albuquerque: University of New Mexico Press.

Wolfgang, M.E. (1996). A Tribute to a View I Have Opposed. Journal of Criminal Law and Criminology, $86(1), 188$.

Zimring, F.E., \& Hawkins, G. (1997). Crime Is Not the Problem: Lethal Violence in America. Oxford University Press. ISBN 0-19-513105-3

Zwillich, T. (2015). Quietly, Congress extends a ban on C.D.C. research on gun violence. Public Radio International (P.R.I.). Retrieved May 21, 2021, from https://www.pri.org/stories/2015-0702/quietly- congress-extends-ban-cdc-research-gun-violence 